\title{
HOUSING TENURE, RESIDENTIAL MOVES AND CHILDREN'S EDUCATIONAL PERFORMANCE IN ACCRA, GHANA
}

\author{
C. Mahama ${ }^{1}$ and B. Campion ${ }^{2}$ \\ ${ }^{I}$ Institute of Local Government Studies, Accra, \\ ${ }^{2}$ Faculty of Renewable Natural Resources, KNUST, Kumasi.
}

\begin{abstract}
Research has shown that non-conventional factors like housing and residential experiences during childhood have impacts on children's success. Given the critical importance of human capital accumulation in Ghana, it is significant from policy standpoint to recognise factors and mechanisms that are relevant to the next generation's educational performance. This paper attempts to identify the impacts of housing tenure and residential moves on the educational performance of children. The research focused on Junior Secondary School (JSS) leavers in Accra. Chronological information of the Pupils during childhood on residential moves and their educational performance between the ages of 12-17 (JSS level) was collected. The results of the analysis indicate large disparities in educational outcomes between children with different housing tenures and strong residential mobility experiences. Even after taking into consideration a set of rich endogenous factors, a positive home ownership effect and a negative residential moves effect remain with significant magnitudes.
\end{abstract}

Keywords: Housing tenure, residential moves, educational performance, Accra.

\section{INTRODUCTION}

Children are the biggest fortunes of any society. Thus, the extent to which they succeed in their education directly determines the level of the country's prosperity. Unfortunately, most countries especially those developing, have not done much research into the educational development of their children.

Recent research attempts have discovered that non conventional factors like housing and residential experiences during childhood have impacts on children's success (Astone and Mclanahan, 1994; Aaronson, 2000; Dalstra et al., 2006; Cutler et al., 2007). Of particular importance are two separately investigated but closely related issues: whether tenures of housing of parents and whether residential moves experienced during childhood, have a real impact on children's educational performance (Green and White, 1997; Boehm and Schlotmann, 1999; Pribesh and Downey, 1999; Pettit and McLanahan, 2003; Ssewamala et al., 2010).

Given the critical importance of human capital accumulation in Ghana, it is significant from policy standpoint to recognise factors and 
mechanisms that are relevant to the next generation's educational performance. The home is the setting where children spend majority of their time and its influences should therefore not be underestimated. Though much work has been done in the US and Europe, the issue of housing tenure and residential experience of children is missing in Ghanaian literature. This paper attempts to bridge this gap by contributing to the understanding of the above discussion using data from Ghana. Previous literature tends to examine only one aspect of children housing experience: housing tenure or residential moves but hardly both. It stands to reason that households having chosen to own a home, either due to internal attitudes or higher moving costs, are less likely to move frequently than households who have chosen to rent. This study therefore sought to identify the impacts of housing tenure and residential moves on the educational performance of children in some communities of Accra.

Given equal family income and other background opportunities, children growing up in owner-occupied homes are expected to have more privacy, more quietness and more favourable study environment than children growing up in rental housing. In the same vain, long distance residential moves usually lead to children's school switching and might therefore put a long-lasting negative impact on a child's later educational development (Humke and Schaefer, 1995).

In reviewing the literature, one of the major revelations has been that, the factors of home owning and residential stability work through so-called neighbourhood effects to affect children's educational outcomes. Several researchers have pointed out that home owners tend to have much higher incentives to invest in neighbourhood-specific social capital than renters (Leventhal and Brooks-Gunn, 2000; Shinn and Toohey, 2003). Accordingly, if we have trust in hypothesised human capital externality of good neighbourhood, which has widespread believers and a growing body of empirical sup- port (Borjas, 1995; South and Baumer, 2003), we have good reason to expect children of home owners who have not moved to have a higher probability to study well than children of renters due to residential moves.

Residential moves destroy existing neighbourhood network, making children lose most of their old friends and put them in a totally new neighbourhood that consumes time to adjust each time (Pettit and McLanahan, 2003). On the contrary, if households did not move frequently, as the time of staying in the same community increases, parents will watch children grow up with less psychological distress or problems in an environment with increasing friendly climate (Wickrama and Bryant, 2003). Psychologists have often suggested that, the number of friendly neighbours, the level of community safety and riches of neighbourhood amenity can be of critical importance to the health and behavioural development of children (Stiffman and Hadley-Ives, 1999; Shinn and Toohey, 2003). Apparently all these factors need time to develop and cultivate.

Only a limited number of studies have attempted to identify the externalities of home ownership to children's successes in school. Green and White (1997) reported a rather surprisingly large advantage of home ownership in preventing children drop out from school during age of 17-18, even across three different data sets and after controlling the endogenous tenure selection biases. Recent research supports the idea that parent's home owning matters to children's educational development and later success (Boehn and Schlotmann, 1999; Aaronson, 2000; Pettit and McLanahan, 2003; Ssewamala et al., 2010).

As a comparison, the issue of impacts of residential moves on children's educational achievements has been recognised much earlier and explored more frequently in the children education literature, mostly by psychiatrists. Empirical evidences accumulated to date generally agree that frequent moves, especially long- 
distance moves in early childhood, hurt children's later education achievement and suppress their economic sufficiency potential (Astone and McLanahan, 1994; Humke and Schaefer, 1995; Pribesh and Downey, 1999; Temple and Reynolds, 1999). It is important to state here that existing literature in this field are obscure to policy debates for small sample size and a variant of methodological problems.

\section{METHODOLOGY}

Up to date, no theoretical models have yet been developed to answer the causal relationship between housing environment experienced during childhood and educational outcomes. The observed strategy - the data telling the story will therefore be adopted for the purpose of this research.

In this paper, the age of completion is used as proxy indicator for the educational performance of a child: whether a child has by age 15 graduated with a junior secondary school certificate and whether the performance will see him/her to the next stage in the educational hierarchy. Admittedly, this surrogate indicator has a number of limitations. For example, it is not necessarily bad for children to stay longer in (junior) secondary schools or even drop out early if parents and or children thought it were a better option than graduation at normal time or some other personal reasons. Furthermore, on graduation, the inequality of educational achievements in terms of knowledge acquired and learning ability is indistinguishable here. One may think of grades of junior secondary school, or something similar, as a better indicator of children's educational outcomes and or a better prediction for children's future successes, but such kind of data will not be correctly divulged by the students.

Despite the above, it is the view of the authors that, graduation from senior school at normal time gives a fairly good summary of both opportunity and achievement for children across different population groups. Another observation is that since education is costly, efficiency consideration applies too. Early drop out or longer schooling than normally expected, no matter how they made sense from individual perspective, caused externalities to the society and were not socially desirable. Accra is the seat of government in Ghana. Compared to other cities, it abounds in administrative (local and international organisations and businesses) and service industries. There is therefore the tendency to either voluntarily or involuntarily move to Accra to work or transact businesses.

A number of suburbs (Nima, Cantonments and Abeka) were selected in the Accra metropolis after carefully studying the demographic characteristics of these communities from the reports of the statistical service. Nima is predominantly a migrant and rundown settled community with residents mainly from Northern Ghana. The main occupation of the people is petty trading. Islam is the main religion of the community. In each community a very popular basic school that serves majority of residents in the locality was chosen for the study. This was to reduce the effects of pupils from different communities that are enrolled in such schools. In Nima, the Roman Catholic JSS popularly known as RC JSS was selected in this community because of its unique characteristics: easy access and popularity as a top brand public school in the community. More than $80 \%$ of the pupils of the school live in Nima.

Abeka is a middle class community with residents mainly employed in the public service and other salaried jobs. St Charles Lwanga JSS is a public school serving the community. Its central location to the public makes it an ideal school for most pupils. In Cantonments, a first class residential area, Christ the King was selected for the study. The inhabitants are mostly those in the higher income group and top public officials. In an attempt to reduce the influence of the type and quality of the schools on the output, the researchers chose top-class public schools with reputation for quality in the three different communities. It was therefore assumed that the setup differs only in the aspects 
concerning the communities e.g. job types, income levels, residential types, housing tenure to mention but a few.

Five housing tenure forms are distinguished in Ghana: owner-occupied houses (typical of residents of Nima and Cantonments), tenantoccupied houses (typical of Abeka and Cantonments), tenant-occupied apartments (typical of Abeka), tenant-occupied room and family houses (typical of residents of Nima and Abeka). The property tax is relatively undeveloped in Ghana. As a result, it was not possible to determine in advance which category of household was owner-occupied or rental or always on the move. It was therefore decided that this should be ascertained from the parentrespondents.

Three different categories of questionnaires (herein called Children, Teachers, and Parents) were administered in each of the selected public schools. In each school one class was randomly picked for each level (or form) of JSS 13 and interviewed. Questionnaires were given to the same pupils to take to their parents to be completed over the weekend and returned the following week (Table 1). All teachers who teach the selected classes were interviewed to ascertain the academic performance of the pupils by evaluating parent and student responses. The performance of the pupils who have moved within the past five years was chronologically studied from the information provided by the parents. Parents were used because they could best provide information on the child's performance in previous schools. Each class was then divided into a lower half and upper half and categorised as low performers (LP) and high performers (HP) respectively.

The differences in residential moves and educational performance was found using analysis of variance (ANOVA) and agglomerative hierarchical cluster analysis looking at the dissimilarity using squared Euclidean distance with unweighted pair-group average of responses. The main variables that affect educational performance of children were isolated by use of principal components analysis (PCA).

\section{RESULTS AND DISCUSSION}

Residential movements and educational performance

The first task of data construction was to accurately measure the educational attainment of the pupils (Figures 1 and 2). The sample suggests that $68 \%$ of the youth in the study areas had finished their junior secondary school by age 15 (and qualified to the next stage). Out of those who finished at a later age, $71 \%$ said they had at one stage moved and therefore had to repeat a class at their new address. Sixty seven percent of these moved families resided in Abeka, $15 \%$ in Nima and $18 \%$ in Cantonments. Most of these people who moved were mostly middle income earners such as civil and public servants who were being transferred from one place to another. Nima has a low income population who are mainly petty traders and this

Table 1: Numbers of questionnaires administered to the different respondents in the selected study areas

\begin{tabular}{lccc}
\hline Study Area & $\begin{array}{c}\text { No. of Students } \\
\text { Interviewed }\end{array}$ & $\begin{array}{c}\text { No. of Teach- } \\
\text { ers Inter- } \\
\text { viewed }\end{array}$ & $\begin{array}{c}\text { No. of Parent } \\
\text { Questionnaires } \\
\text { Received/Sent } \\
\text { Out }\end{array}$ \\
\hline Nima & 117 & 3 & $97 / 117$ \\
Abeka & 132 & 3 & $126 / 132$ \\
Cantonment & 96 & 3 & $77 / 96$ \\
Total & $\mathbf{3 4 5}$ & $\mathbf{9}$ & $\mathbf{3 0 0 / 3 4 5 ( 8 7 \% )}$ \\
\hline
\end{tabular}


might be the reason for the limited relocation rates in the area.

As much as age of completion may not be the best measure of success, longer stay in school increases the cost of training a pupil not withstanding the psychological trauma the child goes through. Even though this study did not investigate the effect duration of education has on pupils, it is generally the tendency for pupils to make fun of the older ones in class, espe- cially if they are not performing well. In cases where performances are not good, it could lead to them dropping out. It should therefore be the policy maker's responsibility to carefully investigate the issues of school failures with special reference to expenditure, efficiency and age of completion.

Pupils from Cantonments who had moved in or out at one stage or the other in their educational career still completed their school at age 15 .

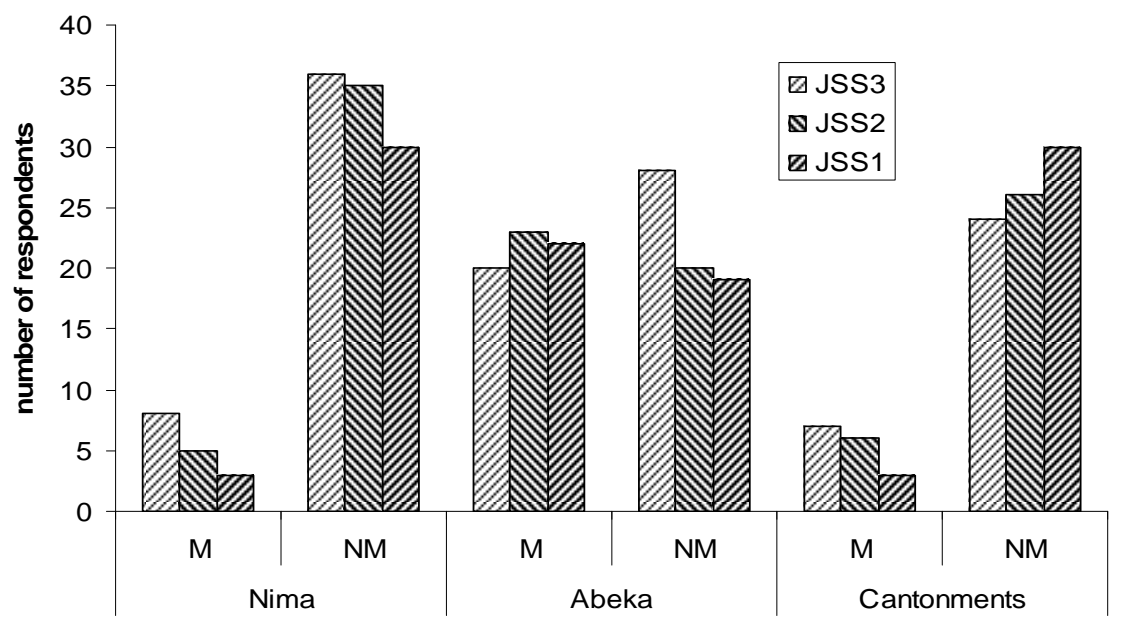

Fig. 1: Educational stage of pupils and residential moves in the selected study areas $(\mathrm{M}=$ moved, $\mathrm{NM}=$ not moved $)$

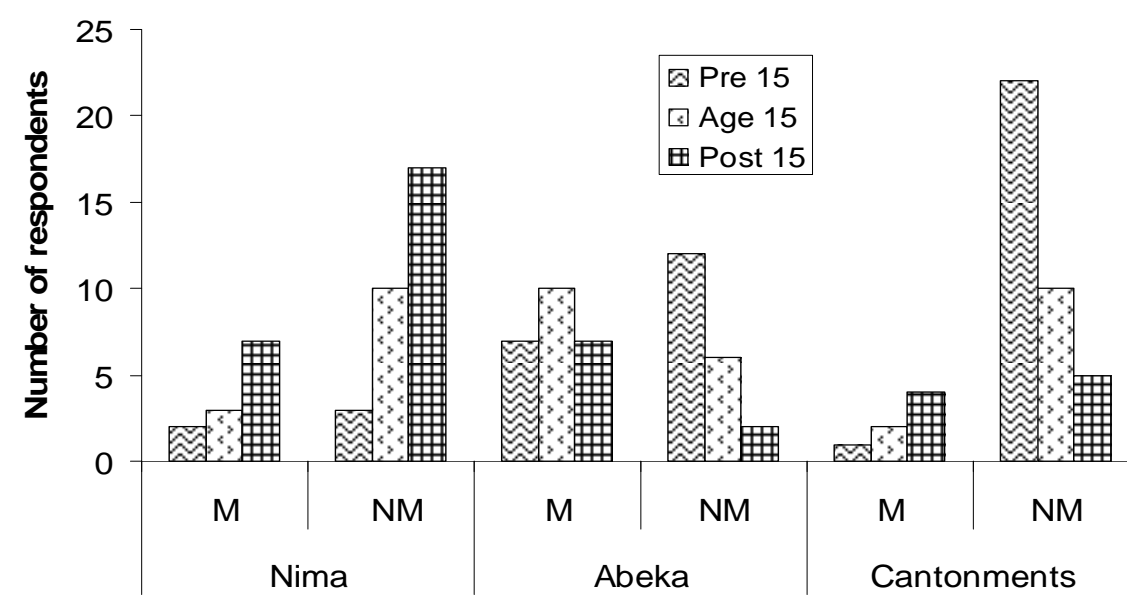

Fig. 2: Residential area and age of completion of pupils in the selected study areas $(M=$ moved, $\mathbf{N M = n o t ~ m o v e d})$ 


\section{0}

Mahama and Campion

This could be due to other extraneous variables that were not investigated. It is the norm that children from these families start school earlier and their parents would invest in extra tuition at home such that the children may not need to repeat a class even if they moved. It was also observed in this study that girls completed at a relatively younger age than the boys. On average, girls had a $6 \%$ higher probability to graduate from junior secondary school by age 15 than boys, but this advantage seemed slightly stronger among high-income families in communities of Cantonments and Abeka.

Performances of children growing up in big families (more than 5.1 persons per household) (Ghana Statistical Service, 2002) seem to be marginally lower than those from small families (less than 5.1 persons per household). This could probably be due to less attention from parents, less money spent on each child and less private environment for studies at home.

Children from Nima appear to be gravely disadvantaged in terms of the general quality of schools in the area, income of parents and poor community infrastructure. Immigrant families' disadvantages are actually not driven by their ethnic identity but rather their heavy residential concentration in less developed suburbs which suffer inferior child educational opportunities. A child's educational performance in this area could therefore be attributed more to environmental factors rather than residential movements.

With respect to the residential variable, we distinguished early childhood (age 10-15) from later childhood (16-18) with the aim to check whether the two periods had different impacts on children, as suggested by Astone and Mclanahan, (1994) and Green and White (1997). We found only a small proportion of families switched their tenures between the two periods. For example, less than $3 \%$ of the households who were home owners before they moved became tenants in the latter period. Following that, we found out that it was not necessary to further investigate this insignificant percentage on a child's performance. The switching from tenants to home owners was even less. In pooling the data and comparing residential moves with performance, pupils who did not move but improved or had a stable academic performance was significantly different $\left(\mathrm{R}^{2}=59 \%, \mathrm{~F}<0.0001\right)$ from the other conditions (Figure 3 ).

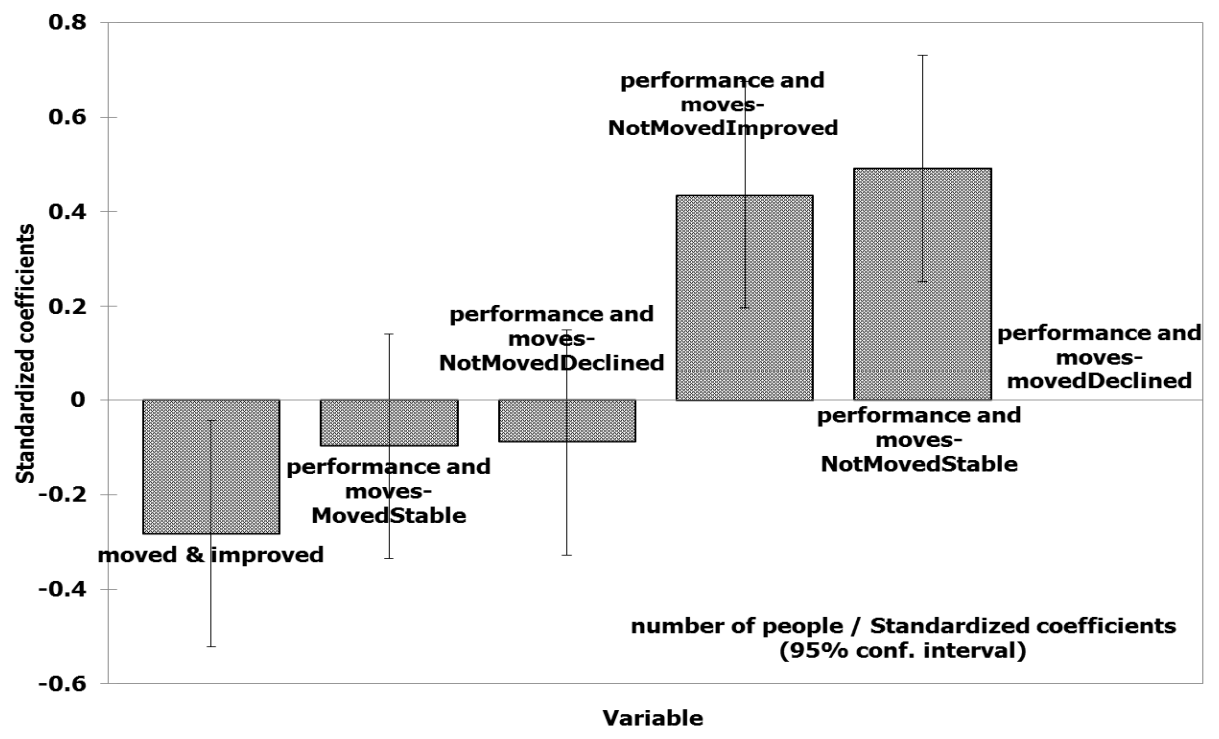

Fig. 3: The results of an ANOVA of residential moves and educational performance of pupils in the selected study areas

Journal of Science and Technology 다 KNUST April 2011 


\section{Tenure type and educational performance}

The tenure types identified in these selected study areas were much varied (Figure 4). Cantonments had predominantly owner-occupied and tenant occupied housing; Nima was typified with family holdings and rental (room) housing types while Abeka had all five identified housing tenure types. Home owners are on the average easy to find and live in goodquality neighbourhood even when frequently moved, while renters will on average experience much more difficulties to find decent housing when moved to new location.

Housing tenure has influence on families whether they moved or not. Owner-occupied and tenant-occupied tenures share great similarities in their stability and income group as could be observed in Cantonments. These respondents were in the high income category. In such job positions, movement was very minimal. It was observed that, while $24 \%$ of respondents in the high class area did move, movement did not involve their whole families because they were either home owners or had rented complete houses for their families to stay behind. A comparatively high majority of the movements were by those in the middle level residential area of Abeka who were mostly in tenant-occupied housing or familyowned accommodation. These people may by virtue of the type of job or position be on frequent transfers and mostly moved with their families. The three study communities are significantly dissimilar in housing tenure and educational performance of pupils in the selected schools (Figures 5 and 6). It is however, worthy to note that students of Abeka at JSS 3 were completely different from those in JSS 1 and 2 . This may be due to parents leaving children behind during their moves or extra effort of teaching, learning and guidance at the JSS 3 stage in Abeka.

\section{Extraneous factors and educational perform- ance of a child}

Apart from the above factors that have been considered for the study, several other factors affect a child's educational performance in Ghana. The distribution of the variables according to a principal component analysis (Figure 7) is quite weak with a variability of $63.43 \%$ accounting for high performers in rental apartments and family housing and low performers from rental apartments. These three groups of students best describe the three communities in terms of housing tenure and educational performance. Extraneous factors (remaining

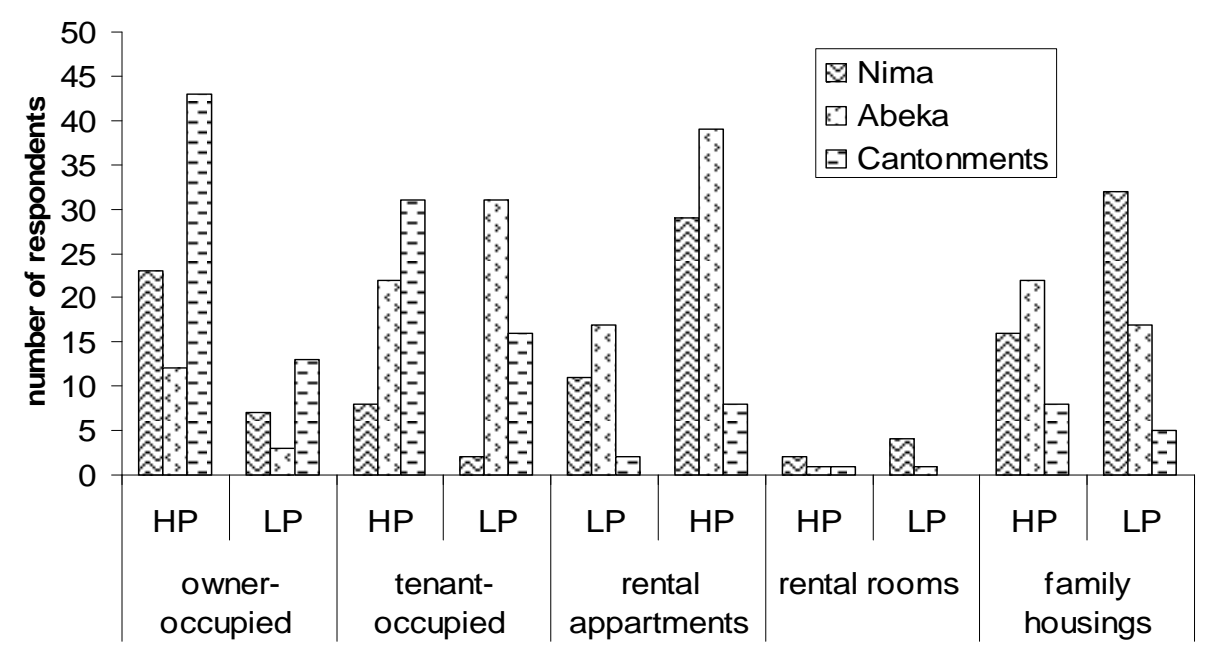

Fig. 4: Housing tenure and educational performance of pupils in the selected study areas ( $\mathrm{LP}=$ low performers, $\mathrm{HP}=$ high performers) 
$36.57 \%$ ) may be biological, type of parentage, income of parents, community facilities, type of schools, local government policies etc. These factors were not investigated because they were beyond the scope of this research. We reiterate here again that the research was to estimate the effect of tenure types and residential moves rather than specifically indicate the extent of the influence which may be as a result of presenting superficial associations that essentially resulted from some omitted variable effects.

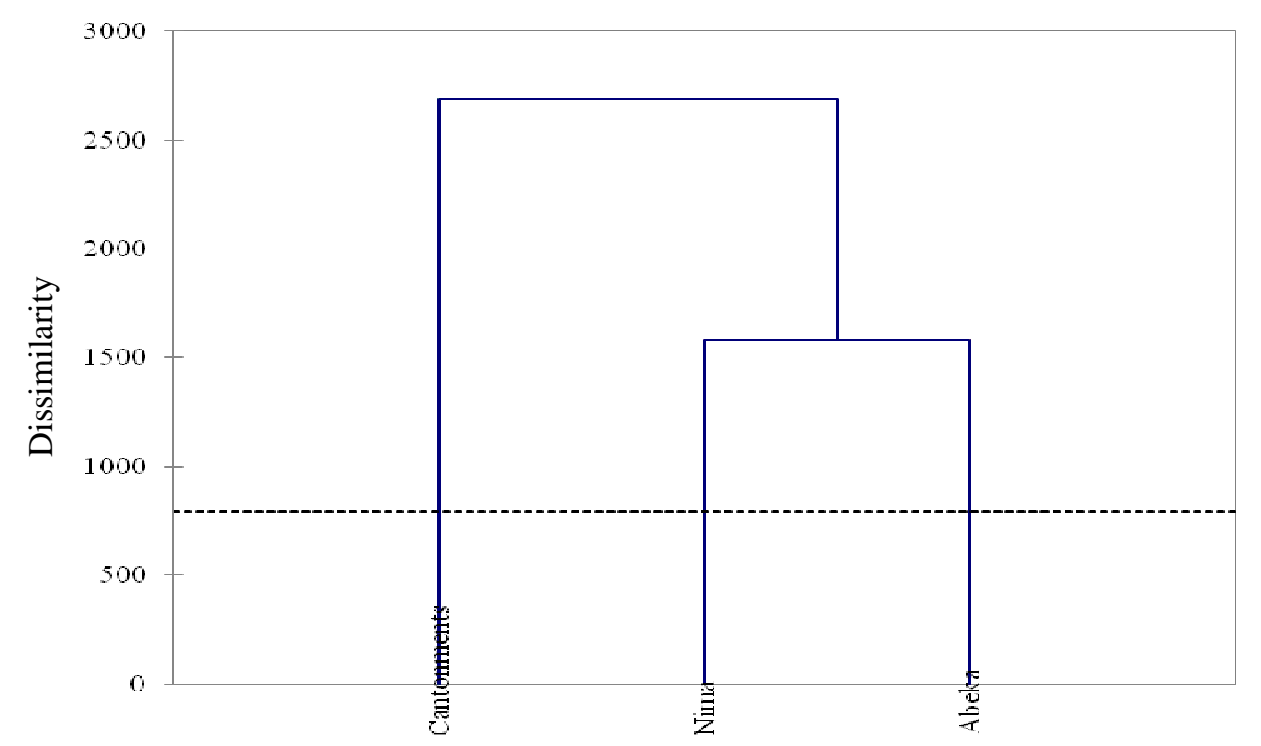

Fig. 5: Dissimilarity, matrix of housing tenure of parents of pupils in the selected schools

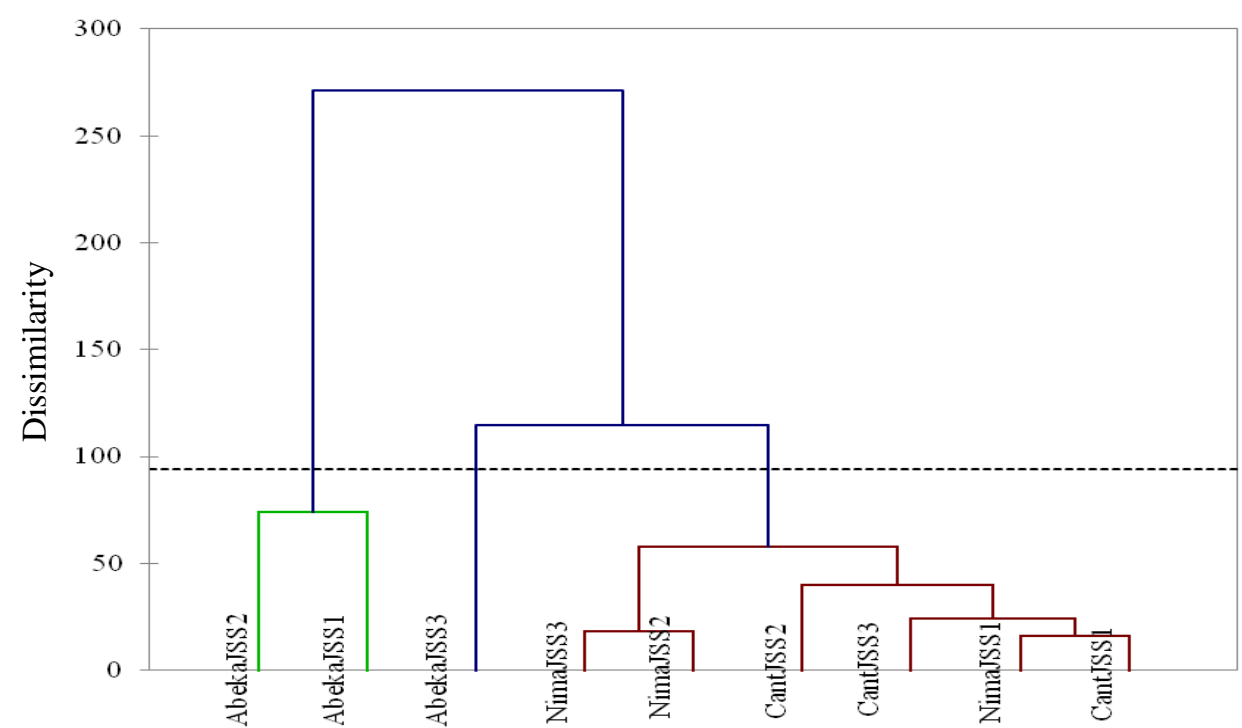

Fig. 6: Dissimilarity matrix of educational performance of pupils in the three study schools in Accra 


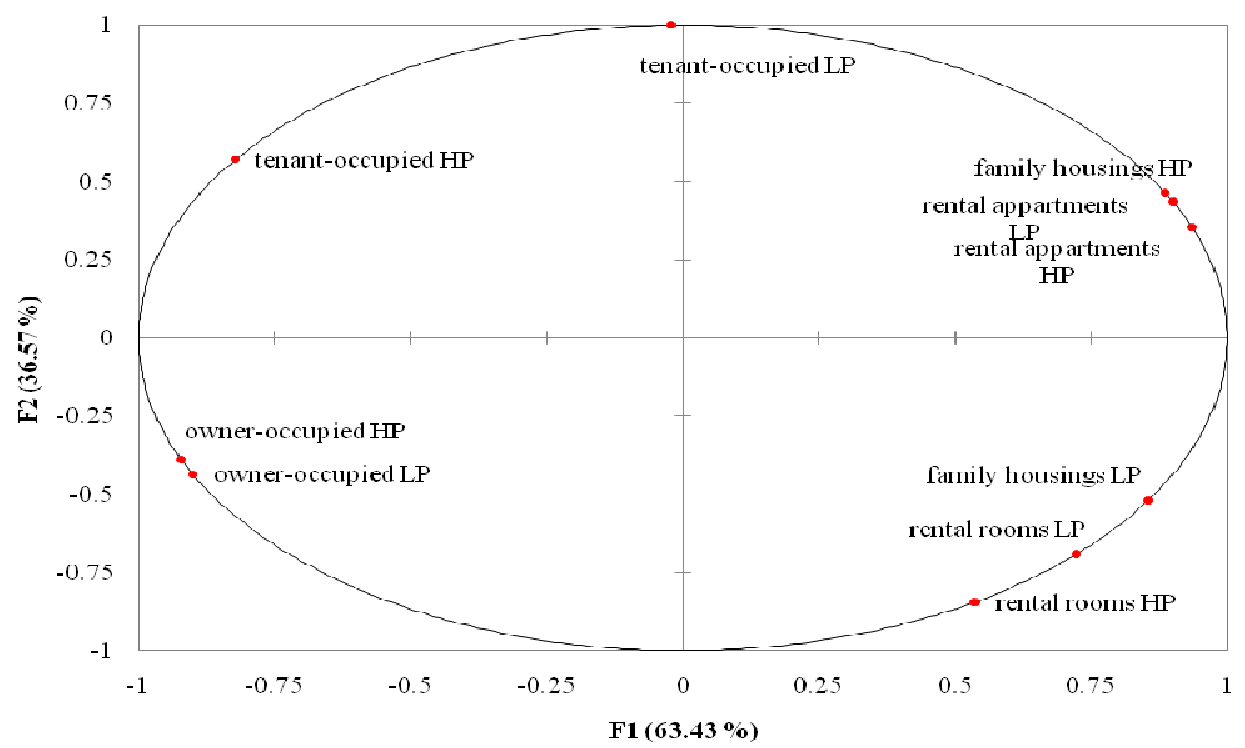

Fig. 7: Graphical representation of the PCA for housing tenure and educational performance of pupils ( $L P=$ low performers, $\mathrm{HP}=$ high performers)

CONCLUSIONS AND POLICY IMPLICATIONS

The key concern for this paper was to estimate the effect of housing tenure and residential moves on the educational performance of children in Accra. This paper contributes to recent mounting debates on the social implications of household experiences with coherent estimates of the impacts of housing tenure and residential moves. From the discussion, it is seen that home ownership was highly favoured in terms of child academic performance over rental tenure. This is likely to add to the current debates on housing policy in Ghana.

A wide array of positive externalities believed to be associated with home ownership, such as boosting civil virtue and citizen's responsibility, constitute the main rationale to encourage ownership tenure. It is important to state here that there are also widespread reasons against home ownership such as favourite tax treatment, which gives emphasis to the fact that, such policy consumes too much social resource. Recently, a substantial number of papers along the hypothesis of Oswald (1999) suggest that home ownership produces social costs (such as the 2005 Ghana Budget Statement which allocated 150 million Ghana cedis for low cost housing construction) by reducing job mobility and raising natural rate of unemployment. But if home owning really matters to the child's success and owning a house is not only for parents' consumption needs but also for the good of the children, the future of our society's prosperity, it will further support the arguments for home ownership policy as enshrined in the Works and Housing Minister's Report on providing shelter for Ghanaians.

If we conclude that residential moves are harmful to children and residential mobility matters, what is the moral argument for it then? One may say that, when parents move, they have carefully considered the possible effects to their children against competing benefits and act in the interest of the entire family. These are household choices that need to be made by the family. Can it also be said that when parents move, they hardly consider the interest of their kids? Or in the case of national interest or the risk of losing ones job? If this is so then the externality of their residential mobility choice on children should be internalised to some ex- 
74

tent. In this regard, the Ghana Government should be willing to discourage household moves by such means as equalisation development policy in regions and encouraging home ownership.

Education is costly. This study is therefore significant from a policy stand point if it is to help reduce hazards of early dropouts and graduation failures. Basically, this study lends support to both theses: home ownership matters to children and that residential mobility matters to children.

\section{REFERENCES}

Aaronson, D. (2000). A note on the benefits of home ownership. Journal of Urban Economics 47(3): 356-369.

Astone, N. M. and Mclanahan, S. S. (1994). Family Structure, Residential-Mobility, and School Dropout-a Research Note. Demography 31(4):575-584.

Boehm, T. P. and Schlotmann, A. M. (1999). Does home ownership by parents have an economic impact on their children? Journal of Housing Economics 8(3): 217-232.

Borjas, G. J. (1995). Ethnicity, Neighbour hoods, and Human-Capital Externalities. American Economic Review 85(3):365390.

Cutler, D. M., Glaeser, E. L. and Vigdor, J. (2007). When are Ghettos Bad? Lessons from immigrant segregation in the United States. NBER Working Paper No. 13082. National Bureau of Economic Research, Cambridge, MA.

Dalstra, J. A. Kunst, A. E. and Mackenbach, J. P. (2006). A comparative appraisal of the relationship of education, income and housing tenure with less than good health among the elderly in Europe. Social Science \& Medicine 6(8):2046-2060.
Ghana Statistical Services (2002). 2000 Рориlation and Housing Census: Summary Report of Final Results. Accra, Ghana

Green, R. K. and White, M. J. (1997). Measuring the benefits of home owning: effects on children. Journal Urban Economics. 41 (3): 441-461.

Humke, C. and Schaefer, C., (1995). Relocation - A review of the effects of residential mobility on Children and adolescents. Psychology 32 (1): pp 16-24.

Leventhal, T. and Brooks-Gunn, J. (2000). The Neighbourhoods They Live In: The effect of neighbourhood residence on Child and Neighbourhood outcomes. Psychological Bulletin 126 (2): 309-327.

Ministry of Works and Housing (2003). Providing Shelter for Ghanaians. Works and Housing Minister's Report on Housing 2003 Accra, Ghana.

Oswald, A. J. (1999). The housing market and Europe's unemployment: A non-technical paper, Warwick University.

Pettit, B. and McLanahan, S. (2003). Residential mobility and children's social capital: evidence from an experiment. Social Science Quarterly 84 (3): 632-649.

Pribesh, S. and Downey, D. B. (1999) Why are residential and school moves associated with poor school performance? Demography 36(4):521-534.

Shinn, M. and Toohey, S. M. (2003). Community contexts of human welfare. Annual Review of Psychology 54: 427-459.

South, S. J. and Baumer, E. P. (2003). Interpreting community effects on youth educational attainment. Youth \& Society 35 (1):3-36. 
Ssewamala, F. M., Karimli L. Hanc, C. and Ismayilovab, L. (2010). Social capital, savings, and educational performance of orphaned adolescents in Sub-Saharan Africa. Children and Youth Services Review 32(12):1704-1710.

Stiffman, A. R. and Hadley-Ives, E. (1999). Impact of Environment on adolescent mental health and behaviour: Structural equation modelling. American Journal of Orthopsychiatry 69(1): 73-86.
Temple, J. A. and Reynolds, A. J. (1999). School Mobility and achievement: Longitudinal findings from an urban cohort. Journal of School Psychology 37(4):355377.

Wickrama, K. A. S. and Bryant, C. M. (2003). Community context of social resources and adolescent mental health. Journal of Marriage and the Family 65(4):850-866. 